\title{
An Analysis of the Credit Service System in Chinese Public Libraries Based on Sesame Credit - A Study on Hangzhou Public Library
}

\author{
Weiran Zhang ${ }^{1, a}$ and Jens Mathis Rieckmann ${ }^{2, b, *}$ \\ ${ }^{1}$ Hangzhou Public Library, Hangzhou, China \\ ${ }^{2}$ Beijing Institute of Technology, Beijing, China \\ awrzkids@126.com, brieckmann@bit.edu.cn \\ ${ }^{*}$ Corresponding author
}

Keywords: Credit service system, Public library, China, Hangzhou.

\begin{abstract}
Recently, the construction of a social credit system has become a hot topic and has gotten a lot of public attention. Public libraries, as an important part of the public service system in China, have launched credit services to promote the establishment of Credit City by cooperating with Sesame Credit ${ }^{1}$. However, during the implementation of this service, some problems are emerging. The lack of an efficient management of readers' dishonest behaviors, the unbalanced range of target readers, and the shortage of a mechanism for cooperation among public libraries are main challenges that need to be faced. Based on the theory related to Internet financial credit platforms and the practice of social credit systems' construction, this paper analyzes the current situation and presents approaches to solve arisen problems.
\end{abstract}

\section{Introduction}

On July $17^{\text {th }} 2012$, the State Council of the People's Republic of China approved the agreement to adjust the member units and main responsibilities of the inter-ministerial joint conference for the construction of a social credit system [2]. In 2014, the Planning Outline for the Construction of Social Credit System (2014-2020) was issued and on July 18 ${ }^{\text {th }}$ 2017, guided by the National Development and Reform Commission, the Summit on Credit City Development in China hosted by the Xinhua News Agency and the Hangzhou Municipal Government was opened [2].

The idea of putting personal reading record into a credit service system and building a personal image of credit based on an advanced IT (information technology) system to decrease the readers' potential dishonest behaviors, to provide services for individual user groups, to improve the overall literature service in libraries, and to provide an easy, boundless and effective system to borrow media from different public libraries are drivers to establish and use a credit service system in Chinese public libraries. It also provides an enrichment of awareness and common sense on Internet finances and credits as an educational task, especially for young and older people. Additionally, the advantage of getting useful feedbacks about and from the patrons of public libraries can contribute to sustainable standardized services and is another main target of the credit service in public libraries.

\section{Literature review on credit service in public libraries}

The topic credit service in public libraries is still novel, therefore and not many academic papers are published on this topic. In the Western world, the cooperation between public libraries and a credit scoring system from a private company are not available yet. So far many articles deal with credits concentrating on the relationship between credit and library, from a macro perspective. Wang [3] considers credit as an economic concept brought into the library community in view of a market economy background. Authors who consider credit services and systems predominantly focus on

\footnotetext{
${ }^{1}$ Sesame Credit is developed by the Ant Financial Services Group, an affiliated company of the Chinese Alibaba Group [1].
} 
monetary systems, and deal mainly with the field of research with regard to economic or management subjects $[4,5]$.

Since 2014, while Sesame Credit has first been introduced into public library communities [6], scholars have started to observe this phenomenon from a micro perspective, and put forward an application in a new area and are discussing the feasibility. While credit service was developed prosperously in 2017 [7], there are only a very few papers with a focus on public libraries. Till now, most of the papers circle around the practice of public libraries [8], and pay little attention to the huge influence of Internet credit platforms and the potentials it may contribute to public library communities. Choosing a cross-disciplinary perspective, this paper takes a critical look at how implementation and practice of this service go on, and discusses a proper development as well as an introduction of quality control.

\section{Introduction of credit service in public libraries}

As already mentioned, the credit service in public libraries is a recent developed novelty, a development that accelerates and involves more and more institutions. The following chapter gives an overview of the development in China and the target research area in Hangzhou.

\subsection{Start of credit service in public libraries in China}

Credit is the mutual relationship of trust between people, units, formed during the producing and trading processes [9]. The concept of credit in public library communities refers to the contract relation between libraries and patrons. Patrons' credit is related to the obligation and responsibility while using libraries' resources. The typical examples of embodying such a credit service are Jincheng Municipal Library, Wenzhou Library and Xining Library [10]. Their self-built readers' credit record fits for their own situations and is easy to adjust. Therefore it may not easy to be transferred to other libraries. Besides, it has no connection with the construction of a social credit system.

The concept of credit in public library communities has enriched gradually the construction of social credit systems and the development of Internet credit services. The credit service in public libraries discussed in this paper is the practice of the combination of public library service plus Sesame Credit, the free service executed by public libraries based on the Sesame Credit system.

\subsection{Credit service in public libraries in Shanghai and Hangzhou}

In December 2015, Shanghai Library initiated the exploration of the cooperation between public libraries and Sesame Credit. By extending services to residents (with ID and temporary ID) without deposit, simplifying the administrative process of registration for people with a high credit score, the library has made reading more convenient citywide. On April $23^{\text {rd }} 2017$, Hangzhou Public Library has started to offer credit service by cooperating with Sesame Credit, including no-deposit registration, no readers' card, online order, and door-to-door delivery. On September $2^{\text {nd }}, 2017$, this service has enlarged patrons' group by dropping the access credit score to 550, which is the setting start score of Sesame Credit. The amount of newly registered readers supported by the new policy is almost 30,000 [11]. The annual online borrow volume reaches up to 7,000 transactions [11]. On November $26^{\text {th }}$ 2017, Hangzhou Public Library issued the Hangzhou Declaration of Credit Service in Public Libraries, with 27 other public libraries, aiming to promote this service model to the whole country [7]. This credit service, initiated by Shanghai Library, developed by Hangzhou Public Library, taking advantage of the Internet personal credit platform, has not only saved the cost of self-built system, but also innovated the service to inspire patrons' good reading behaviors, so as to contribute to the construction of social credit system.

Based on the current practice of credit services operated in public libraries, the content of public libraries using Sesame Credit service can be concluded as following: cancel registration fee by credit 
score, borrow books or reading books online, listen to audio books via personal Internet platform, offer book-delivery by Internet of things [12]. The milestones of the development of credit service in public libraries are summarized in Fig. 1.

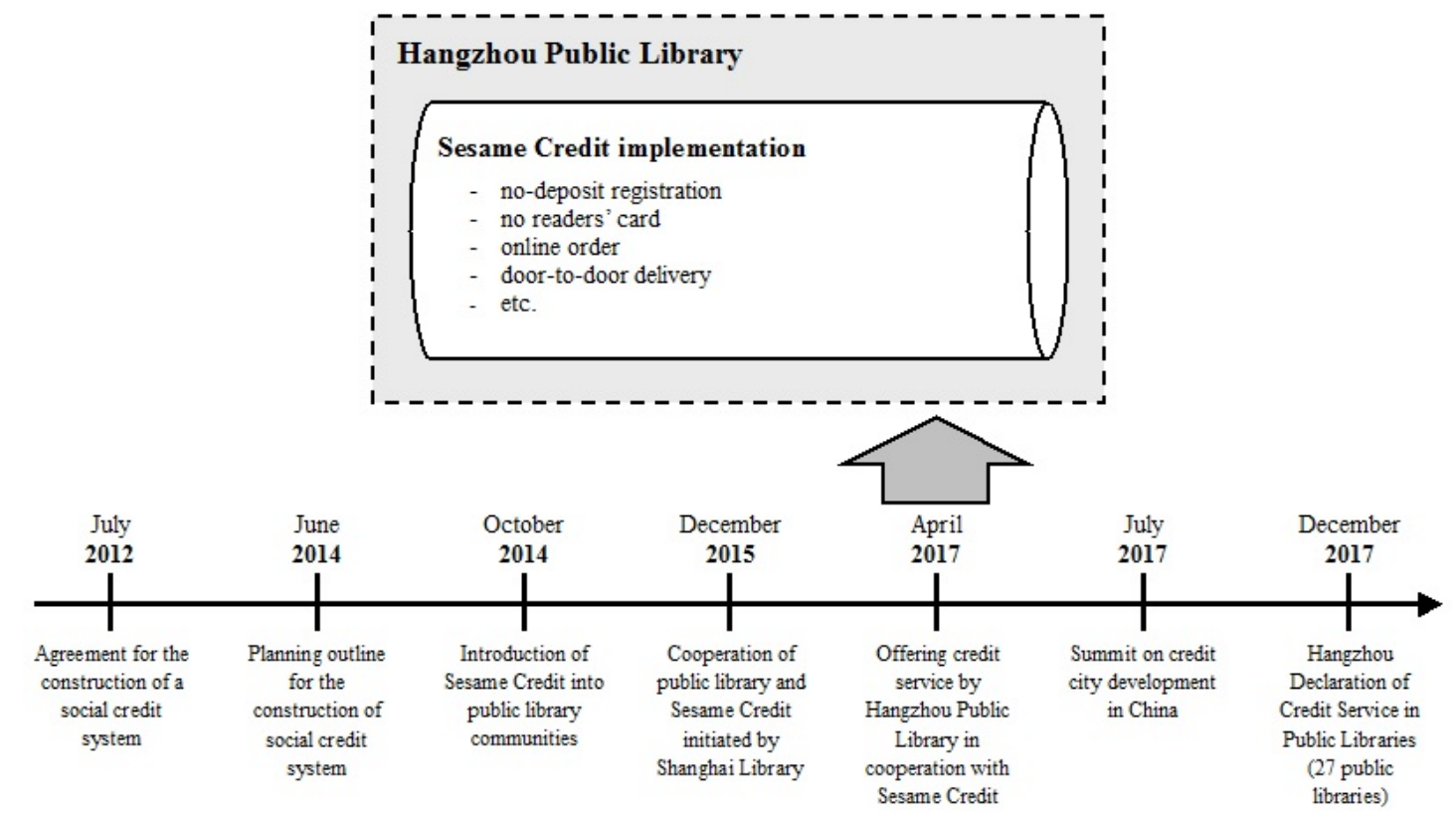

Fig. 1. Milestones of development of credit service in public libraries and Hangzhou Public Library implementation

\section{Challenges of current credit service}

The credit service poses different challenges. These challenges need to be analyzed in order to improve and guarantee a proper development.

Firstly, the credit service is lacking the guidance of readers' behaviors, especially of the discredit behaviors. The common discredit behaviors in public libraries include destroying books on purpose or failing to obey the borrow rules. Using fines is the traditional way for public libraries to solve these problems. However, fines can only limited lead readers to form good reading habits and prevent discredit behaviors in the future. Nowadays, the registration fee has been replaced by credit score, but the common way dealing with discredit behaviors in most public libraries is still to use fines. Therefore, it is obviously that an advanced strategy is needed to reduce discredit behaviors while readers enjoy credit service in public libraries.

Secondly, the credit service is not optimized for the needs of different patrons' groups. Readers have diverse reading demands from public libraries. Usually, the services offered by public libraries are targeted to different groups, which can be divided by age, gender as well as interests or career. In recent years, the public libraries worldwide have taken an important role to fulfill the goals of the United Nations 2030 Agenda for Sustainable Development [13]. Many of their services have paid close attention to special groups, such as children, women and older people. According to the statistics of credit service in Hangzhou Public Library from April 2017 to September 2017, 91.88 percent of the new registered readers are born in the 1980s and 1990s [12], which may be reasonable, considering that young consumers are more familiar with Alipay and frequently use Sesame Credit. However, there is no evidence shown that children and older people have no need for credit service. While implementing the credit service, it is a necessity for public libraries to think more about how to improve it by meeting the various needs of different patrons.

Thirdly, the credit service is implemented by every public library itself. Although in November 2017, Hangzhou Public library has united other 27 public libraries to release a Hangzhou Declaration on Credit Service in Public Libraries, there is no agreement settled on the common standard of formal and informal communication among public libraries. Since the construction of the social credit system has been launched in the whole country, it is impossible to ignore the diversity and difference 
among provinces and cities. The credit service, which has a close relationship with local economic and cultural development, would not be the same in different public libraries. Therefore, there is a need for a platform for public libraries to share experiences, which can not only accelerate the development pace of the service, but also avoid making similar mistakes and thus support successful implementation. Additionally, it would contribute to the sustainable development of credit service in public library communities, a good atmosphere of a good reading behavior in libraries and even the construction of the social credit system.

\section{Measures based on the features of internet credit system}

Since the credit service in public libraries has adopted the idea of Internet credit service, it is important to learn how the Internet credit service providers fight against discredit behavior in order to solve similar problems in public libraries. In the traditional financial industry, the bank will publish the information of discredit people, and will cancel some rights or options of them, such as the loans. That has a direct impact on people's economic and living conditions. For example, if they cannot get the loans from banks, they cannot afford a house for living or they will lose their own company. Nowadays, the Internet credit service will add some extra benefits to prevent people from being discredit. The idea is to reward instead to punish customers to foster good behavior. Consideration could be given to offer coupons or similar bonuses to reward the ones who have permanent a good credit behavior. The better performance the consumer has, the bigger the rewards one obtains. The extra benefits are usually brought from third parties, which are companies having cooperative relation with Sesame Credit ${ }^{2}$. By a deep and efficient social relationship, Sesame Credit has created a win-win situation: benefits for consumers, companies and itself.

As an extension only Shanghai Library in 2014 has put readers' credit information into the Shanghai municipal public credit service platform, where readers' discredit information will be exposed [14]. Considering most of the Chinese cities do not have such well-developed platform as in Shanghai, so it is impossible for them to do similar measures right now. A future direction is that public libraries should also cooperate with other social groups to enrich their service. A more advanced and valuable credit service will be cherished by patrons and prevent them from discredit behaviors. The credit service in Hangzhou Public Library for example, started from canceling registration fee to offering online book-borrow, toy-borrow; all measures, which displayed how convenient the credit score in a library can be for patrons. There is a great potential to enlarge the service to more benefits in daily life.

Besides, public libraries can use big date technology to encourage readers to build personal reading record, which will be collected and transferred into performance of credit service. The data used in the Internet credit system, based on big data, is totally different from ones in traditional financial industry. The public credit system has characteristics focusing on people's behavior, psychology and social networking. Therefore, using big data in a proper way will help people shape good behavior. Profiling the personal reading image by one's own borrow behavior, which is recorded during the use of public libraries' credit services, will be an efficient way to encourage credit behavior. The better the reading behavior is, the better is the image of reading people. The more positive image people have, the less is the incentive for them to act against good reading behavior. The more good images of reading emerge, the less discredit behaviors will be occur in the future.

Secondly, according to the experience of American personal credit system on information collection, management and usage, scholars He and Jiang [15] mentioned that the design of Chinese social credit should follow the principle of objectiveness and fairness. Credit service in public libraries, as an important support of educating the importance of credit in society, should follow such principles. Therefore, the service should consider the needs from different groups, and public libraries should treat older people and children carefully while they are enjoying credit services.

\footnotetext{
2 The authors are aware that the offered rewards also present a business activity to generate a direct financial profit for Sesame Credit. This fact is not further discussed because the generation of income is not the main focus of this article.
} 
As to children, credit service should be a good chance for them to know the importance of credit as a citizen in society. To cherish the credit record is a good habit to form a responsible and sustainable handling in daily life as an adult. Considering they are not allowed to have their own account on credit score, public libraries could connect their accounts to their parents. To some extend, it would contribute to the atmosphere of internal education effect in a family. The parents would become a model for their children, so it also helps them developing and keeping self-discipline as a good reader in public libraries and a good citizen in society.

As to older people, credit service will help them to know more about credit, finance and related information literacy. An investigation issued in September 2017 form American Credit Cooperation Association showed that older people are more likely to be victims of financial crimes [16]. Credit service in public libraries should be a bridge to connect older people and the Internet credit service. To let them know more about Internet credit service would be a good way to avoid being cheated. Besides, Sesame Credit offers other products related to share economy such as share bike service. If the older learn how to deal with the credit service in public libraries, they could transfer their new knowledge and enjoy share bike service.

Thirdly, let the union take an important function. In Japan, the social credit system is greatly motivated by industry communities, which have a big influence on the economy in the country, especially in personal credit communities [17]. The advantages of the cooperative way are in the low cost of communication, and the clear rules on rights and obligations that are set. Considering the credit service in public libraries, it is also a feasible way of using a powerful organization for communication among libraries. Hangzhou Declaration of Credit Service in Public Libraries mentions that an equal, cooperative and sharing teamwork makes libraries powerful; credit is the foundation to unit public libraries' services without boundary, which means that it is agreed by public libraries to let every member improve the service by itself, and share and use the improvements together, especially when it is not diverse and mature enough [18].

As to specific measures, improvements could be designed in two areas: on one hand, to actively improve the union including Hangzhou Public Library and the other 27 members. By making comprehensive mechanisms on communication and exchange, it will help its members to improve the service. On the other hand, it could be useful to cooperate with the National Library Association. By using existing mature mechanisms to expand the influence of the credit service and make communication more efficient.

\section{Summary}

The implementation of a social credit system in public libraries creates many challenges. The usage of the Sesame Credit system needs more improvements. This paper analyzes the development and current situation and points out different strategies to improve and keep the quality using a social credit system in public libraries. However, there is still a long way to go for the construction of a credit system in the public library area. Meanwhile, the privacy protection of patrons' credit information is a sensitive and important topic, which should be dealt with very carefully. How to keep these information and use them properly should be discussed and regulated in the future.

\section{References}

[1] Alibaba Group Holding Limited (ed.), Our Business, 2018. Retrieved on 2018/05/02 from https://www.alibabagroup.com/en/about/businesses.

[2] Yuandiancredit (ed.), Shehui xinyong ti'xi jianshe zhi "dili fenjin de wunian“" (The inspiring five years of the construction of social credit system'), 2017. Retrieved on 2018/04/07 from https://www.creditchina.gov.cn/xinyongyanjiu/xinyongyanjiuhuicui/201712/t20171201_98144. html. 
[3] X. Li, Xinyong shi tushuguan zai shichang jingji zhong de tongxingzhen ('The credit is the passport of library in market economy'), Tushu qingbao daokan ('Journey of Library and Information Science'), vol. 20(3), pp. 94-95, 2010.

[4] S. R. Aiyagari, R. A. Braun and Z. Eckstein, Transaction services, inflation, and welfare, Journal of Political Economy, vol. 106(6), pp. 1274-1301. DOI: 10.1086/250047.

[5] M. Gillman, The welfare cost of inflation in a cash-in-advance economy with costly credit, Journal of Monetary Economics, vol. 31(1), pp. 97-115. DOI: 10.1016/0304-3932(93)90018-B.

[6] Guotu yanjiuyuan ('Research Institution of National Library of China') (ed.), Shanghai tushuguan fachu guonei shouzhang xinyongjiehsuka ('The first credit reader card was issued by Shanghai Library'), Guojia tushuguan xuekan ('Journey of the National Library of China'), vol. 28(6), pp. 113, 2014.

[7] Hangzhou Municipal Bureau of Culture, Radio, TV, Film, Press and Publication (ed.), China, "Xinyong tushu jiehuan fuwu" zhuli xinyong hangzhou jianshe ("Credit service in Hangzhou Public Library" promote the construction of credit city of Hangzhou'), 2017. Retrieved on 2018/04/07 from http://www.hangzhou.gov.cn/art/2018/4/3/art_1256344_17263052.html.

[8] G. Li, B. Fan, J. Wu, S. Chu, J. Xu and F. Gao, Yinwei xinyong, suoyi jiandan ('Simple because of credit: conversation of experts about credit service of public library by writing'), Tushu yu qingbao ('Library and Information'), vol. 28(5), pp. 1-10, 2017. DOI: 10.11968/tsyqb.1003-6938.2017086.

[9] L. Chen, Xinyong yu tushuguan ('Credit and Library'), Tushuguan jianshe ('Library Development'), vol. 27(5), pp. 110-112, 2004.

[10]Y.-Q. Zhang, Gonggong tushugguan duzhe xinyong guanli moshi ji anli fenxi, ('Reader credit management models of Chinese public libraries: case studies'), Tushuguan luntan ('Library Tribune'), vol. 37(3), pp. 123-127, 2017.

[11]W. Zhang, "Hulianwang+" shidai xia gonggong tushuguan yuedu tuiguang fuwu tantao, ('Discussion on reading promotion services of public libraries in Internet plus era: take Hangzhou Public Library as an example'), Tushuguan yanjiu yu gongzuo, ('Library Science Research and Work'), vol. 39(1), pp. 65-68, 2018.

[12]X. Shou, D. Ye and Y. Weng, Gonggong tushuguan kaizhan xinyong fuwu de shijian yu celue ('Research on the practice and value of credit service in public libraries'), Yi hangzhou tushuguan weili (Taking Hangzhou Public Library as an Example), vol. 39(5), pp. 15-19, 2017. DOI:10.11968/tsyqb.1003-6938.2017088.

[13] International Federation of Library Associations and Institutions (IFLA) (ed.), Libraries, Development and the United Nations 2030 Agenda, 2017. Retrieved on 2018/04/07 from https://www.ifla.org/libraries-development.

[14]Y. Lin and Q. Han, Shanghai tushuguan dazao quanming xinyong tushuguan: yi xinyong mian yajin banzhenbanzheng ('Building a credit library in shanghai library: credit without deposit'), 2015. Retrieved on 2018/04/07 from http://sh.people.com.cn/n/2015/1201/c13476827222879.html.

[15]D. He and B. Jiang, Mianxiang shehui guanli de geren xinyong pingjia zhibiao tixi yanjiu yu sheji ('Research on design of social personal credit evaluation system'), Dianzi zhenwu ('E-Government'), vol. 125(5), pp. 97-103. DOI: 10.16582/j.cnki.dzzw.2013.05.010.

[16]J. Xu, Diaocha biaoming meiguo laonianren yi zao jinrong zhapian ('Investigation shows that American older people are easier to be the targets of financial crime'), 2017, Retrieved on 2018/04/07 from http://www.xinhuanet.com/fortune/2017-10/17/c_1121816867.htm. 
[17]J. Li, G. Li and X. Gao, Guowai shehui xinyong tixi fazhan moshi bijiao ji qishi ('The comparison analysis of different models of social credit system in different countries'), Xiandai guanli kexue ('Modern Management Science'), vol. 27(6), pp. 80-81, 2008.

[18]S. Chu and C. Tu, Gonggong tushuguan xinyong fuwu de yuanqi jiazhi he chuangxin yiyi ('The origin, value and innovative meaning of public library's credit service'), Tushuguan xuekan ('Journal of Library Science'), vol. 40(1), pp. 3-7, 2018. DOI: 10.14037/j.cnki.tsgxk.2018.01.002. 